\title{
Religion and Nation: the Case of the Republic of Macedonia
}

\author{
Stojan Slaveski, European University, Skopje \\ stojan.slaveski@eurm.edu.mk \\ and
}

Igor Gelev, Ministry of Defense of the Republic of Macedonia,

igelev@yahoo.com

\begin{abstract}
Historically to ensure unity in a country where religion played a significant role, it was required that the country have only one religion i.e., "the sovereign of the country determines its religion." This politicization of religion led to religious wars within and among the nations of Europe; hence the principle was replaced by one of secularity, i.e. separation of religion from the state. Modern liberal democratic societies are secular. However, since the end of the Cold War there has seen a re-politicizing of religion. The Republic of Macedonia is no exception to this trend. Under the constitution, the state is a secular one and religion is segregated. In practice, however, this separation is not fully achieved. The paper investigates the interlocking relationships that have come to exist between politics and religious communities in the Republic of Macedonia in light of nation-building process. The paper concludes that the success of the modern nation-building process is determined by the respect for the existing cultural matrix, which in itself articulates the values of two confessions - Muslim and Orthodox Christian. Religious groups, in essence, are calling for peace, tolerance and respect for the "other", which can contribute to building a multicultural society. On the other hand, disrespect and manipulation of religious feelings may affect adversely the building of the sense of a single nation. In a society such as Macedonian, inter-religious cooperation is very important. Only this concept carries any promise for the future of the contemporary Macedonian nation.
\end{abstract}

Keywords: politics, religious communities, nation, religion 


\section{Introduction}

Until the mid 17th century and beginning of the formation of the modern (secular) international system of states, religion was the key ideology that often provoked political conflicts between social groups within countries and between countries. But after the Treaty of Westphalia in 1648 and the development of the modern nation-state, first in Western Europe and then in the European colonies and the rest of the world, at both the intrastate and international level, the political importance of religion declined significantly (Haynes Jeffrey 2009).

However, at the beginning of the 21st century, religion is once again being politicized. This trend has been particularly noticeable in the period since the end of the Cold War. And this is especially true of the so-called "world religions" (Buddhism, Christianity, Islam, Judaism, Hinduism and Confucianism). Many analysts point to the Iranian Revolution (1978-79) as a moment of "re-awakening of religion". For many years, Iran, just like Turkey, had been an example of a secular state patterned on the Western liberal model. Moreover, many other parts of the world witnessed the emergence of states where religion played an increasingly important role. Europe was partly an exception because most of its countries emphasize their secularity having displaced religion from the public into the private sphere. But, no one can deny that religion is an important resource that can be used in nation-building. ${ }^{1}$ According to Mike Pierce (2012), "it is not possible to build a complete and well-functioning society in which religion is completely absent." There are two approaches to the utilization of religion in nation-building, i.e. organic and voluntary one.

Religion has a special role in the organic approach to nation building. Hence, when it comes to identity, religion sometimes bulks larger than ethnicity. Religion is one of the earliest and most general expressions of humanity that connects people. Hence, many

\footnotetext{
${ }^{1}$ Unlike in European countries, the role of religion in the United States is quite prominent. More than half of Americans say they regularly attend religious services, which is three to four times more than European norms. Even on the American currency, the dollar, the words "In God we trust" are written. The importance of religion in public life in the United States is partly explained by the fact that it is an element of the cultural heritage of the 17th and 18th-century settlers, many of whom were AngloProtestants. This is an important cultural factor that is present in the daily lives of Americans, and even in the formation of the American multi-ethnic yet civil nation.
} 
politicians have used it in the creation of their nation-states. In that case religion has a special place in the constitution of the country.

The problem occurs when there is more than one religion in the country: The political elite cannot use the religion of the majority as a means of homogenizing the society, because it creates a feeling of inferiority among other religious communities. ${ }^{2}$ In such cases, the "ethics and morals" that are basic tenets of each religion need to be brought into play. However, sometimes, due to different interests, religions cannot act together to accomplish the goals of the national state. That is the cue for the secularists to make their entrance, "to limit them (the religious groups) in that impulsive rejection of each other". This is the essence of the voluntary approach in building the nation.

\section{Historical Perspective on the Role of Religion in Macedonia}

Multi-religious societies are a defining feature of life in the Balkans (Poulton and Taji-Farouki 1997). In today's Republic of Macedonia, along with the ethnic Macedonians, who are predominantly Christians, there are ethnic Albanians, who are mostly Muslims. ${ }^{3}$ During the Ottoman Empire, which was an Islamic theocracy, the so-called "millet" system

\footnotetext{
${ }^{2}$ As a positive example of how different religions can live together we can point out the Ottoman and the Hapsburg Empires.

${ }^{3}$ Albanians are divided into two major cultural groups, Ghegs and Tosca. Chegs in the XIX century inhabited the higher areas of Kosovo, the western part of today's Republic of Macedonia and the northern Albania today. While Tosca were living in southern Albania, around Prespa Lake and in northwestern Greece, Ghegs tribes were organized, disobedient and rebellious. Unlike them Tosca, who lived in more urban environments were less inclined to war. During the Ottoman Empire, the majority of Ghegs have given up the Christian religion to become Sunni Muslims. The majority Tosca also converted to Islam while a fraction remained Christians - Catholic or Orthodox. But unlike their northern compatriots they belong to less traditional Bektashi sect. Overall, these cultural and dialect groups haven't had developed an Albanian national consciousness until the beginning of the XX century. Until then, Muslim Albanians considered themselves Turks, but also members of a particular clan who have a specific regional identity. On the other hand, for the Christian Albanians, religion and place of residence had a great role in their identification. Unlike Ghegs for Tosca tribal affiliation had much more meaning. See Duncan Perry, "Conflicting ambitions and shared destinies: Past, present and future of Albanians and Macedonians", in Rudometof Victor, Macedonian Question, (Skopje: EuroBalkan Press, 2003), 367. (Рудометоф Виктор, Македонското прашање, (Скопје: Евро-Балкан Пресс, 2003), 367).
} 
was established for non-Muslim communities. Muslims in the Ottoman Empire enjoyed certain advantages over non-Muslims. On the other hand, the "millet" system of faithreligious self-government gave a degree of autonomy to the Christian population, for whom religious affiliation had much greater importance than ethnicity. In other words, ethnic identity was closely tied to religious affiliation that is essence of the organic approach to building a nation.

The end of 18th and the beginning of the 19th century saw a beginning of the process of forming autocephalous national churches, which marked the end of the ecumenical community of Balkan Orthodoxy. The newly established national churches had the task of assisting in building the nation and the state. On the one hand, they were a means of assimilating the enslaved peoples. The population in Macedonia was the target of assimilation by the autocephalous churches of the new nation states (Greece, Bulgaria, Serbia). Particularly fierce was the fight between the Greek Patriarchate and the Bulgarian Exarchate over the Christian population in Macedonia (Karakasidou 2003, 83). The Balkan wars and the division of Macedonia only complicated the process "because of the more acute awareness among some people that they were not Bulgarian, Greek or Serb, but Macedonian" (Loring 2003, 42).

Thus at the beginning of the 20th century, the primary role in the development of the Macedonian ethnic identity was played by church affiliation, while for the Albanians it was the Muslim religion, in addition to "language and culture" (Perry 2003, 378), had a decisive influence on the definition of their ethnic identity. After the First World War, with the establishment of the Kingdom of Yugoslavia, at first named the Kingdom of Serbs, Croats and Slovenes, ethnic Macedonians and ethnic Albanians had an inferior status. This was an additional incentive for both groups to work on their projects for ethnic homogenization (ibid. 380). li was a period of peaceful coexistence between the Macedonians and the Albanians, yet their rarely mixed with each other. ${ }^{4}$

\footnotetext{
${ }^{4}$ Although they had a common enemy, the two groups "never united forces." During the Second World War most of the ethnic Macedonians joined the Yugoslav Partisan movement which guaranteed it would recognize their distinct national identity. On the other hand, ethnic Albanians from the territory of Macedonia in great portion joined the "Bali Kombetar", an anti-communist movement, which fought to create a Greater Albania which will include Kosovo and Western Macedonia. The other part of the Albanians joined Albanian partisan movement. But relations between the Albanian and Yugoslav partisans were often strained so that mistrust and hostility between Macedonians and Albanians have grown. In the postwar period in the newly created Republic
} 
Since the 1944 decisions of the Anti-fascist Assembly for the National Liberation of Macedonia (ASNOM) and the establishment of the modern Macedonian state, the state has maintained a wide-ranging interest in relations between itself and its religious communities. To this end, a number of regulatory acts were adopted. In all legal acts, the emphasis is placed on freedom of conscience and religion as a private matter; separation of religious communities from the state and freedom in exercise of religious activities and religious rituals; prohibition of abuse of religion for political purposes; equality of citizens in rights and obligations regardless of religious, racial and national origin etc.. ${ }^{5}$ This approach to religion can be named as voluntary in building the contemporary Macedonian nation. All believers are guaranteed the right of free expression of religious feelings, but the use of religion for anti-state objectives is not permitted. In other words, this voluntary approach to building the nation allows religion as a significant social resource to contribute to the development of the nation, but prohibits any abuse of religion.

In the period of cohabitation in the Yugoslav Federation, the Macedonian leadership supported the Macedonian Orthodox Church (MOC) as the largest religious community in the country, especially in its bid to win ecclesiastical independence from the Serbian Orthodox Church (SOC). The secular leadership saw this as a way to strengthen selfdetermination and Macedonian identity. These efforts culminated in the decision by the Macedonian Orthodox Church in 1967 to proclaim autocephalous status. However, the move was not accepted by the Serbian Orthodox Church (SOC). The rationale for the SOC's opposition was that one country (Yugoslavia) could not have two autocephalous Orthodox churches. ${ }^{6}$ The status of the Socialist Republic of Macedonia (SRM) as a federal unit was an argument for SOC to oppose autocephaly for the Macedonian church. For SOC the SRM was just "an administrative federal unit" hence it would only recognize the autonomous status of MOC. For this reason, the MOC was reproved for "tempting to destroy the brotherhood and unity" of the state. ${ }^{7}$ In other words, MOC was impairing the affirmation of the

of Macedonian although religious tolerance has been practiced there has been one veiled hostility because of the conflicting goals of the groups, creating a Macedonian state and nation against the unification of Albanian territories into a single country.

${ }^{5}$ See the official website of the Commission for Relations with Religious Communities and Religious Groups: http://www.kovz.gov.mk

${ }^{6}$ At that time there was no Montenegrin Orthodox Church.

${ }^{7}$ Interview with protodeacon Slave P. Projkovski for the weekly Citizen (Citizen, no. 27, November 3, 2012, 36). 
"Yugoslav political nation". However, according to, the Macedonian political elite, aware of the importance of the Church for the construction of the Macedonian ethno-nation, "orchestrated the creation of the autocephalous Macedonian Church and for the most part accepted the modernist vision of statehood" (Keith Brown 2012). ${ }^{8}$ It was generally supported by the Yugoslav authorities. In this period the Socialist Republic of Macedonia took measures toward abolishing certain traditional Muslim customs, such as the wearing of the veil by women (Lederer 2001). The moves aimed at "modernizing" the population and reducing the influence of Islam caused revolt with the ethnic Albanians.

"Church nationalism" in the Balkans, according to Loring M. Denfort (2003) is an attempt by "Balkan nation-states to use the Orthodox churches in order to incorporate in the nation people living outside the country's borders". This applies especially to the ethnic Macedonians and the Macedonian state. ${ }^{9}$ The state tries to strengthen the links between Macedonian ethnic identity and the Christian religion, while on the other hand it seeks to integrate Macedonians living abroad into the ethno-nation. Consequently an attack on the religious identity of the Macedonian ethnic community is seen as an attack on the nation.

The independence of the Republic of Macedonia created conditions for complete freedom of action and equality of religious communities. ${ }^{10}$ However, Article 19 of the 1991 Constitution, which distinguishes the Macedonian Orthodox Church from the other religious communities meant a switch to organic approach to nation-building and a source of friction between Macedonians and Albanians in the first years of independence. So, smaller religious

\footnotetext{
${ }^{8}$ The issue of autonomy of MOC has not been resolved yet. From time to time among the Macedonian public there are allegations for a "union" to be a way of resolving the dispute with the SOC and the isolation which is imposed by other Orthodox churches. It is very sensitive and conditioned solution. First, because it is difficult to guess what will be the reaction of believers to this move of the church and second, this decision needs to be approved from the Vatican. Given the stronger position of the SOC regarding MOC not only in the Orthodoxy but in the entire Christian world then the answer could be perceived.

9 With the establishment of an autocephalous Macedonian Orthodox Church and the state independence, many immigrants from Macedonia to Australia who previously had Greek or Bulgarian national identity embraced the Macedonian ethnic identity.

${ }^{10}$ There was an unsuccessful attempt a cleric (the head of the Orthodox Church, at that time Bishop Mihail) to be elected the first President. This solution certainly would have had negative consequences for the secular state and inter-religious coexistence. Namely, in addition to Orthodox Christians (67\% of the population) there are Muslims (30\%) and Catholics.
} 
communities and religious groups wanted to limit the power and influence of the $M O C$ stemming from the Constitution (Stojanovska 2001).

The Framework Agreement envisaged that in addition to the MOC, the Constitution would include the Islamic Religious Community on an equal basis. But after strong opposition from the MOC, which argued that it was still unrecognized by other Orthodox churches and would lose its primacy, a compromise was reached: After the reference to the Macedonian Orthodox Church, the word "and" was inserted, followed by a list other churches or religious communities: the Islamic Religious Community (IRC), the Catholic Church (CC), the United Methodist Church (UMC), and the Jewish community (JC). ${ }^{11}$ All churches, religious communities and religious groups are separated from the state and are equal before the law. ${ }^{12}$ This clearly shows that there is no state religion and as such it cannot act as the exclusive builder of the nation. This is again a return to voluntary approach.

\section{Contemporary Government's Approach to Macedonian nation-building}

According the Constitution the state is not allowed to interfere in religious matters, nor should religious communities interfere in state affairs. But this separation is not very strict in any secular society. Politics and religious communities are linked in a complex web of relationships. According to Sasajkovski $(2001,429)$, the political engagement of religious communities could be defined as "efforts to build status as an institution... which, rising above day-to-day political divisions, consistently and selflessly works to restore the lost unity of society and state.... ${ }^{13}$. For that reason, he advocates the inclusion of the MOC in discussions "on topics related to national identity". According to him, in the first years of

\footnotetext{
${ }^{11}$ The law allows other religious organizations to apply for government recognition. The government has granted this recognition to 30 religious organizations. In order to obtain the same legal rights and status as the five groups named in the constitution, the law requires aspirant religious communities to register with the courts.

${ }^{12}$ Religious organizations can apply to register themselves as a "church," a "religious community," or a "religious group." These classifications are based on group size, internal organization, and internal hierarchy, and do not bestow different legal rights, benefits, or obligations.

${ }^{13}$ Сасајковски Славејко, „Ревитализација на верските заедници како политички субјекти“, во Панде Лазаревски и др., Аспекти на националната безбедност на Република Македонија, (Скопје: иСППИ, 2001), 429.
} 
independence, the Macedonian Orthodox Church and the IRC essentially did not have status of a "relevant social and political entity." For its part, the IRC uses current conditions to become more visible and influential in daily political developments.

The ruling conservative elite now give greater space and support to the MOC-OA in the everyday life. International Religious Freedom Report for 2014 notes that "the government continued to deny recognition to minority religious groups and maintained its preferential treatment of the MOC-OA." According to the Report, religious groups continued to have trouble obtaining restitution of former properties and permits for new construction. Smaller religious organizations not listed in the constitution, such as the Jehovah's Witnesses ${ }^{14}$, the Bektashi ${ }^{15}$, and the Orthodox Archbishopric of Ohrid ${ }^{16}$, complained that the government did not treat religious organizations not listed in the constitution as the equals of the five named organizations. Most religious groups stated the government favored the MOC-OA by granting it unique tax privileges, providing public properties free of charge, offering funding for the construction of new Orthodox churches, and providing exclusive invitations for its representatives to attend government functions. These other religious groups said the ruling coalition's dominant ethnic Macedonian, and predominantly Orthodox party had politicized religion for its own political gain by appealing to the religious beliefs and identity of the country's majority and by using the MOC-OA $A^{17}$ as a tool to that end (UN State Department 2014).

Given that Macedonian society is multi-religious with five of the numerous religions accorded constitutional status, one cannot talk about an exclusive role that religion might have played in the creation of contemporary Macedonian nation. The largest religious groups are Orthodox Christianity (to which most ethnic Macedonians belong) and Islam (which is followed by most Albanians). Although historically these two largest religious

${ }^{14}$ Representatives of the Jehovah's Witnesses complained that their missionaries were subject to harassment by police when distributing religious material.

${ }^{15}$ The Bektashi complained that they continued to receive threats from individuals with different interpretations of Islam.

${ }^{16}$ The self-declared Orthodox Archbishopric of Ohrid is awaiting a ruling regarding its application to register as a recognized religious organization, which courts had denied on the legal grounds that it could not substantiate the difference between its name and symbols and those of the MOC-OA.

${ }^{17}$ So far, the MOC-OA remained the sole registered Orthodox group, due to the requirement that religious groups seeking recognition not have names or symbols similar to those of an already registered group. 
groups have successfully co-existed, due to the experiences they underwent in the former Yugoslavia, there is a danger of their confrontation.

So far, that danger is minimal; moreover there exists an element that bridges the ethno-religious divide: Albanians who are Christians, and Macedonians who are Muslims. These small religious groups can be a connecting element between the two religions. In addition, religious communities can be a cohesive factor in ethno-political life, when it is divided by the ideological platforms of the political parties; thus religion can play a part in strengthening the ethnic identity of the communities in the state. Therefore, there needs to be a combination of organic and voluntary discourse in the use of religion as a social resource in building the modern Macedonian nation.

\section{Conclusion}

The contemporary nation building process in Macedonia should continue within the existing cultural matrix. Religious groups, in essence, are calling for peace, tolerance and respect for the "other", which can contribute to building a multicultural society. On the other hand, disrespect and manipulation of religious particularity can adversely affect the building of the sense of a single nation. In a society such as Macedonia's, inter-religious cooperation is very important. Only this multicultural concept (combination of organic and voluntary approach) carries any promise for the future of the contemporary nation.

\section{References}

1. Haynes Jeffrey (ed.), Routledge Handbook of Religion and Politics, (London: Taylor \& Francis Group, 2009).

2. Poulton H. and Taji-Farouki, S. (ed.), Muslim Identity and the Balkan State, (London: Hurst, 1997).

3. Rudometof Victor, Macedonian Question, (Skopje: Euro-Balkan Press, 2003).

4. Lederer Gyorgy, "Islam in East Europe", Central Asian Survey (2001), 20(1).

5. Stojanovska G., "Macedonia: Church rage Over Political Reforms". Institute for War and Peace Reporting, BCR292, 31 October 2001, http://www.iwpr.net, accessed on 5.11.2001. 


\section{Securilatity}

6. Сасајковски Славејко, „Ревитализација на верските заедници како политички субјекти“, во Панде Лазаревски и др., Аспекти на националната безбедност на Република Македонија, (Скопје: ИСППИ, 2001).

7. Macedonia, International Religious Freedom Report for 2014, United States Department of State,

(http://www.state.gov/secretary/remarks/2015/10/248198.htm acceded 10.11.2015).

8. Citizen, no. 27, November 3, 2012.

9. Citizen, no. 26, October 27, 2012.

10. Citizen, no. 29, November 17, 2012. 